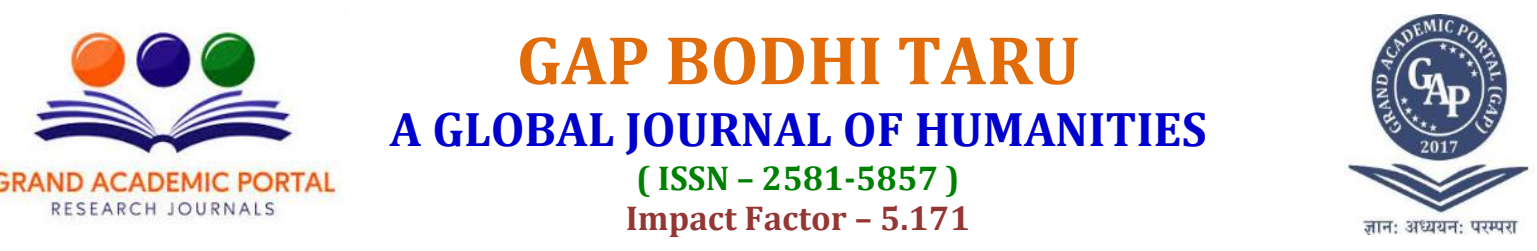

\title{
150 YEARS OF GANDHI AND HIS VIEWS ON EDUCATION: THEN AND NOW
}

\author{
Dr. Preeti Oza \\ St. Andrew's College \\ University of Mumbai
}

PROLOGUE

To the Reader

I would like to say to the diligent reader of my writings and to others who are interested in them that I am not at all concerned with appearing to be consistent. In my search after Truth, I have discarded many ideas and learned many new things. Old as I am in age, I have no feeling that I have ceased to grow inwardly or that my growth will stop at the dissoluti9on of the flesh. What I am concerned with is my readiness to obey the call of Truth, my God, from moment to moment, and, therefore, when anybody finds any inconsistency between two writings of mine, if he has still faith in my sanity, he would do well to choose the latter of two on the same project.

(Harijan, 29-4-'33, p.2) M.K.Gandhi

Mohandas Gandhi, in 1937, proposed a 'New Education', and given his thoughts and ideas about it freely in many speeches, talks, books, newspapers, and periodicals. Interestingly, today the education system of India is also going through a sea-change and incidentally the proposed policy changes are also being discussed extensively by all the stakeholders of the education system under the term' New Education Policy'- NEP.

Gandhiji's ideas in this regard to this New Education did not, of course, suddenly emerge from his brain in 1937, but were the outcome of long years of sustained thought and experience. This article relates to this earlier formative period when he revolted from the prevailing system of education and sought in various ways to substitute it by educational practices more in harmony with his own conception of the function of education. to understand adequately the Basic Education scheme which he formulated in 1937 it is essential to go back to this earlier period where we can see it in origin and growth.

This new scheme came to be called Basic Education. it related to education to be given to a child from his $7^{\text {th }}$ to $14^{\text {th }}$ year. To this was to be added in course of time Pre-Basic and Post- Basic education relating to education before the $7^{\text {th }}$ and after the $14^{\text {th }}$ year respectively. The education covering all these three stages is what is comprised of New Education or Nai Talim.

\section{Section I}

Inadequacy of Prevailing Education:

"The ordinary meaning of education is knowledge of letters. To teach boys reading, writing and arithmetic are called primary education. a peasant earns his bread honestly. He has ordinary knowledge of the world. He knows fairly well how he should behave towards his parents, his wife, his children, and his fellow-villagers. He understands and observes the rules of morality. But he cannot write his own name. what do you propose to do by giving him a knowledge of letters? Will add an inch to his happiness? Do you wish to make him discontented with his cottage or his lot? And even if you want to do that, he will not need such an education. Carried away by the flood of western thoughts, we came to the conclusion, without weighing pros and cons, that we should give this kind of education to the people.

Now let us take higher education. I have learned geography, astronomy, algebra, geometry, etc. What about this? In what way have I benefited myself from those around me? Why have I learned these things? Professor Huxley has thus defined education:

" That man I think has had a liberal education who has been so trained in youth that his body is the ready servant of his will and does with ease and pleasure all the work that as a mechanism it is capable of; whose intellect is a clear, cold, logic engine with all its parts of equal strength and in smooth working order... whose mind is stored with knowledge of the fundamental truths of nature...whose passions are trained to come to heel by a vigorous will...the servant of a tender conscience...who has learned to hate all vileness and to respect others like himself. Such a one and no other, I conceive, has had a liberal education, for he is in harmony with Nature. He will make the best of her and she of him."

If this is true education, I must emphatically say that the sciences I have enumerated above I have never been able to use for controlling my senses. Therefore, whether you take elementary education or higher education it is not required for the main thing. It does not make us men. It does not enable us to do our duty.

I do not for one moment believe that my life would have been wasted, had I not receive higher or lower education. nor do I consider that I necessarily serve because I speak. But I do desire to serve and, in endeavoring to fulfill that desire, I make use of the education I have received. And, if I am making good use of it, even then it is not for the millions, but I can use it only for such as you, and this supports my contention. Both 


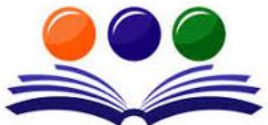 \\ A GLOBAL JOURNAL OF HUMANITIES}

GRAND ACADEMIC PORTAL

RESEARCH JOURNALS

( ISSN - 2581-5857)
Impact Factor - 5.171

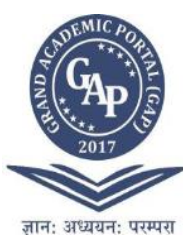

you and I have come under the bane of what is mainly false education. I claim to have become free from its ill effects, and I am trying to give you the benefits of my experience and, in doing so, I am demonstrating the rottenness of this education."

Hind Swaraj (1908), ch. XVIII

"I have never been able to make a fetish of literary training. My experience has proved to my satisfaction that literary training by itself adds not an inch to one's moral height and that character-building is independent of literary training. I am firm of the opinion that the government schools have unmanned us, rendered us helpless and godless. They have filled us with discontent, and providing no remedy for the discontent, they made us despondent. They have made us what we were intended to become, clerks and interpreters."

Young India, 1-6-'21

\section{ON ENGLISH EDUCATION}

Question: Do I then understand that you do not consider English education necessary for obtaining Home Rule? Editor ( Gandhiji): my answer is yes and no. to give millions a knowledge of English is to enslave them. The foundation that Macaulay has laid of education has enslaved us. I do not suggest that he had any such intention, but that has been the result. It is not a sad commentary that we should have to speak to Home Rule in a foreign tongue?

And it is worthy of note that the systems which the Europeans have discarded are the systems in vogue among us. Their learned men continually make changes. We ignorantly adhere to their cast-off systems. They are trying each division, to improve their own status. Wales is s small portion of England. Great efforts are being made to revive the knowledge of welsh among Welshmen. The English Chancellor, Mr. Llyod George is taking a leading part in the movement to make Welsh children Welsh. And what is our condition? We write to each other in faulty English, and from this even, our M.A.s are not free; our best thoughts are expressed in English; the proceedings of our Congress are conducted in English; our best newspapers are printed in English. If this state of things continues for a long time posterity will- it is my firm opinion- condemn and curse us.

It is worth noting that by receiving English education, we have enslaved the nation. Hypocrisy, tyranny, etc., have increased; English- knowing Indians have not hesitated to cheat and strike terror into the people. Now, if we are doing anything for the people at all, we pay only a portion of the debt due to them.

It is not a painful thing that, if I want to go to a court of justice, I must employ the English language as a medium; that, when I become a Barrister, I may not speak my mother tongue, and that someone else should have to translate to me from my own language? Is not this absolutely absurd? Is it not a sign of slavery? Am I to blame English for it or myself? It is we, the English knowing men, that have enslaved India. The curse of the nation will rest not upon the English but upon us.

I have told you that my answer to your question is both yes and no. I have explained to you why it is yes. I shall now explain why it no.

We are so much beset by the disease of civilization, that we cannot altogether do without English education. those who have already received it may make good use of it wherever necessary. In our dealings with the English people, in our dealings with our own people, when we can only correspond with them through that language, and for the purpose of knowing how much disgusted they ( the English) have themselves become with their civilization, we may use or learn English, as the case may be. Those who have studied English will have to teach morality to their progeny through mother tongue, and to teach them another Indian language; but when they have grown up, they may learn English, the ultimate aim being that we should not need it. The object to making money thereby should be eschewed. Even in learning English to such a limited extent, we will have to consider what we should learn through it and what we should not."

Hind Swaraj (1908), Ch. XVIII

Section II

Foreshadowing of a New Type of Education

\section{NEED FOR EXPERIMENTS IN EDUCATION}

There is too much make-believe, self-deception, and submission to convention. The field of education, which holds the seeds of the future of the children of the soil, requires absolute sincerity, fearlessness in the pursuit of truth and boldest experiments, provided always that they are sound and based upon deep thoughts matured and sanctified by a life of consecration. Not every tyro in education may make such experiments. If the field is vast enough for sound experimenting, it is too dangerous for hasty and ill-conceived prospecting such as people in feverish search of gold delight in it.

Young India, 30-9'26 


\section{$\stackrel{0}{=}$ \\ A GLOBAL JOURNAL OF HUMANITIES}

GRAND ACADEMIC PORTAL

RESEARCH JOURNALS

( ISSN - 2581-5857)

Impact Factor - 5.171

EDUCATION IN THE HOME

When I landed at Durban in January 1897, I had three children with me, my sister's son ten years old, and my own sons nine and five years of age. Where was I to educate them? I was loth to send them back to India, for I believed even then that young children should not be separated from their parents. The education that children naturally imbibe in a well-ordered household is impossible to obtain in hostels. I, therefore, kept my children with me. I could not devote to the children all the time I had wanted to give them. My inability to give them enough attention and other unavoidable causes prevented me from providing them with the literary education I had desired and all my sons have had complaints to make against me in this matter. Whenever they come across an M.A., or a B.A. or even a Matriculate, they seem to feel the handicap of want of school education.

Nevertheless, I am of the opinion that, if I had insisted on their being educated somehow at public schools, they would have been deprived of the training that can be had only at the school of experience, or from contact with the parents. I should never have been free, as I am today, from anxiety on their score, and the artificial education they could have had in England or South Africa, torn from me, would never have taught them the simplicity and the spirit of service they show in their lives today, while their artificial ways of living might have been a serious handicap in my public work. Therefore, though I have not been able to give them a literary education either to their or my satisfaction, I am not quite sure, as I look back on my past years that I have not done my duty by them to the best of my capacity. Not do I regret nor having sent them to public schools, I have always felt that the undesirable traits I see today in my eldest son are an echo of my own undisciplined and unformulated early life. I regard that time as a period of half-backed knowledge and indulgence.

I have come in contact with numerous students. I have tried myself or through others to impose my educational 'fads' on other children too and have seen the results thereof. There are within my knowledge a number of young men today contemporaneous with my sons. I don't think that man to man they are any better than my sons, or that my sons have much to learn from them.

But the ultimate result of my experiments is in the womb of the future. My object in discussing this subject here is that a student of the history of civilization may have some measure of the difference between disciplined home education and school education, and also of the effects produced on children through changes introduced by parents in their lives."

Autobiography (1926), pp. 245-48

\section{NATIONAL V/S. GOVERNMENT EDUCATION}

One of our students has gone to jail in Bardoli and many more will go. They are the pride of the Vidyapith. Much as they may desire to do likewise, can students of government institutions dare to do so? It is not open to them to go to Bardoli and help Vallabhbhai, as it is to you. They can only give secret sympathy. What is literary training worth if it cramps and confine us at a critical moment in national life? Knowledge and literacy training are no recompense for emasculation.

Again there is a world of difference between our method of teaching and theirs. For instance, we may not teach English in the way they do. We may give a working knowledge of that language but we may not, without committing national suicide, neglect the mother tongue, and make English the vehicle of our thought. In this national institution, we strive to correct the pernicious practice. We must learn all our subjects through the Gujurati language. We must enrich it and make it capable of expression all shades of thought and feeling.

Then take the teaching of economics. The present system obtaining in government institutions is vicious. Each country has its own economics. German textbooks are different from English. Free trade may be England's salvation. It spells our ruin. We have yet to formulate a system of Indian economics. The same about history. A Frenchman writing a history of India will write it in his own way. The Englishman will write it quite differently. The descriptions of battles between the English and the French will differ with the writers who have described them. Indian history written from original sources by an Indian patriot will be different from that written by an English bureaucrat though each may be quite honest. We have grievously erred in accepting English estimates of events in our national life. Here, therefore, there is a vast field for you and your teachers for original research.

Young India 21-6'-29

\section{Section III}

New Education

\section{NEW EDUCATION TO BE ROOTED IN THE CULTURE AND LIFE OF PEOPLE}

The curriculum and pedagogic ideas that form the fabric of modern education were imported from Oxford and Cambridge, Edinburgh and London. But they are essentially foreign, and till they are repudiated, there never can be national education. for the moment, we are not going to discuss the problem whether it is possible for India to do without European education; ( and in this connection let us say that we regard the English as a mere special phenomenon of the European system.) if India decides in the light of the need there is of fighting Europe 


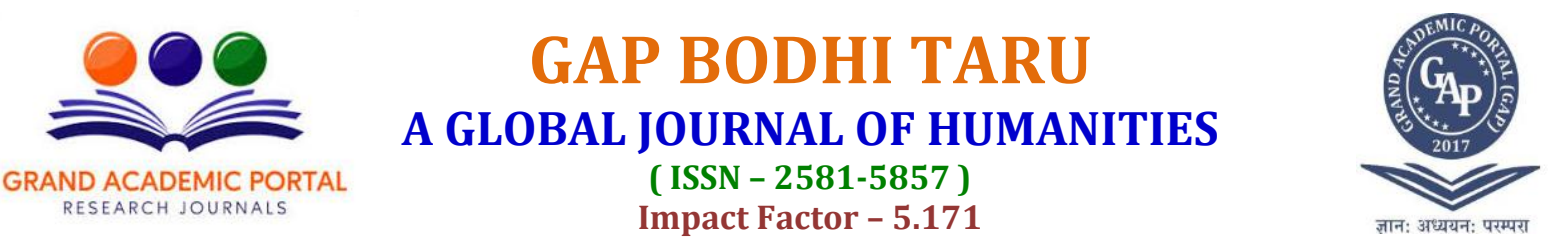

with her own weapons, Industrialism, Capitalism, Militarism, and all the rest, in favor of making counterfeit Europeans of her children, soldiers, inventors of explosives, prostitutors of science, forgetters of God, she must go forward on her path stern and open-eyed, whatever the disaster. But in that case, she should make up her mind to do without national education, for national education will not secure those ends, will not make her sons and daughters fit for the fulfillment of those functions.

The fact to be realized is that India by the very fact of her long-established and elaborated civilization had once the advantage of an educational system of her own, the only thing entitled to be called 'national'. But it was fundamentally distinct from the Anglo-Indian type and from the pseudo-national type that is its decedents. The question then is this: The choice must be clearly and finally made between national and foreign education, the choice of type and archetype, of meaning and purpose, of end and means. It has so far not been made. We are almost certain that the necessity for choosing is hardly realized. As long as confusion on this matter exists, 'national' education cannot flourish. The government is already imparting one type of education in respect of which it is impossible for any purely non-official body to compete."

Young India, 20-3-'24

\section{TO DEVELOP CHARACTER}

There is only one word to the education of the heart- love for education. I do not believe that this can be imparted through books. It can only be done through the loving touch of the teacher. And, who are the teachers in the primary and even secondary schools? Are they men and women of faith and character? Have they themselves received the training of the heart? Are they even expected to take care of the permanent elements in the boys and girls placed under their charge? Is not the method of engaging teachers for lower schools an effective bar against character? Do the teachers get even a living wage? And we know that the teachers of the primary schools are not selected for their patriotism. They only come who cannot find any other employment.

Young India-1-9'21

\section{CONCLUSION}

The importance of providing value education is felt necessary today because the present system of education cannot contribute much to the individual and social development. Value-oriented education does not mean preaching of mere moral sciences or propagating particular religious tenets, but it is imparting knowledge of values considered functional for both individual as well as society. Gandhi's philosophical, religious, economic and social approach and a number of contemporary Gandhian perspectives are relevant to an understanding of human values and social change today. By Gandhian ideals in the education policy, we will be able to inspire the whole world by his ideas of truth, nonviolence, peace, and love.(https://www.mkgandhi.org/articles/value\%20education.htm) 